\title{
Margaret McCartney: Blaming doctors won't reduce antibiotic overuse
}

\author{
Margaret McCartney general practitioner, Glasgow
}

"Doctors write 10 million needless antibiotic prescriptions a year," was the Guardian's headline, ${ }^{1}$ and Mark Baker, director of clinical practice at the National Institute for Health and Care Excellence (NICE), told the BBC that some doctors are a "soft touch" and that "ultimately, if they fail to fall into line, there is always recourse to the professional regulator."2

Furthermore, NICE said, "If successfully implemented, NICE's guidance could help to reduce inappropriate prescribing by $22 \%$ - accounting for 10 million prescriptions," ${ }^{3}$ which led to the Guardian's headline.

I am all for reducing overdiagnosis and overtreatment. I'm chair of the Royal College of General Practitioners' overdiagnosis group. I should be delighted that an influential organisation is keen to reduce iatrogenic harm. But this media coverage has been a disaster.

Where is the evidence that doctors write 10 million unnecessary antibiotic prescriptions a year? NICE told me that the figure was an estimate based on expert opinion from an adviser to the Department of Health, Mike Sharland. When I spoke to him, he told me that it was not a figure that he recognised. It was not in NICE's press release, either; but it was included at a press conference that NICE held to publicise its new guidelines, and it was published in public relations material on NICE's website. I'm willing to think that we can reduce antibiotic prescriptions - but hype of any kind is bad practice.

In any case, raw data do not tell us which antibiotics were unnecessary. We are being asked to prescribe more antibiotics in different populations-for example, regular azithromycin in people with chronic obstructive pulmonary disease. And I'm aware of the tensions that come from a patient who says, "I'm an expert in me," as well as the public reviews that people can leave about the NHS and how "refusal" to prescribe antibiotics can be perceived.

It's easy to prescribe antibiotics. It takes time, energy, and trust not to do so. ${ }^{4}$ This is about culture, and this culture needs first to be understood. NICE's handling of the media can do real world damage. Do we want patients to conclude that the reason for not prescribing antibiotics is not because they are useless but because doctors are afraid of being struck off? We should be honest, share uncertainties with our patients, explain when antibiotics are unlikely to help, relax the NHS culture of "earlier is better" for minor illnesses, ${ }^{5}$ and get better knowledge into common currency - for example, viral coughs last for weeks. How wonderful it would be if NICE had said, "Prescribing antibiotics is hard to get right. We want to support doctors and patients to reduce low value prescribing. Even careful, cognisant doctors are sometimes going to get it wrong, but this is a risk we think is worth taking. Doctors, we will help you get more time to talk with your patients about the things that are important to them. We have your backs."

Competing interests: I have read and understood the BMJ policy on declaration of interests and declare the following interests: I'm an NHS GP partner, with income partly dependent on Quality and Outcomes Framework points. I'm a part time undergraduate tutor at the University of Glasgow. I've written two books and earn from broadcast and written freelance journalism. I'm an unpaid patron of Healthwatch. I make a monthly donation to Keep Our NHS Public. I'm a member of Medact. I'm occasionally paid for time, travel, and accommodation to give talks or have locum fees paid to allow me to give talks but never for any drug or public relations company. I was elected to the national council of the Royal College of General Practitioners in 2013 and am chair of its standing group on overdiagnosis. I have invested a small amount of money in a social enterprise, Who Made Your Pants?

Provenance and peer review: Commissioned; not externally peer reviewed.

Follow Margaret on Twitter, @mgtmccartney

Meikle J. Doctors write $10 \mathrm{~m}$ needless antibiotic prescriptions a year, says NICE Guardian 2015 Aug 18 . www theguardian com/society/2015/aug/18/soft-touch-doctors-write-10m2015 Aug 18. www.theguardian.com/society-

2 BBC Radio 4. Today programme. 18 Aug 2015. www.bbc.co.uk/programmes/b065t3v7.

3 National Institute for Health and Care Excellence. Calls for NHS to curb antibiotic prescribing. 18 Aug 2015. www.nice.org.uk/news/article/calls-for-nhs-to-curb-inappropriateantibiotic-prescribing

4 Brookes-Howell L, Wood F, Verheij T, et al. Trust, openness and continuity of care influence acceptance of antibiotics for children with respiratory tract infections: a four nations qualitative study. Fam Pract 2014;31:102-10.

5 NHS Choices. Feeling under the weather? www.nhs.uk/asap.

Cite this as: BMJ 2015;351:h4697

๑๑ BMJ Publishing Group Ltd 2015 
